\title{
CONTRIBUTION OF EAR AND FLAG LEAF TO GRAIN FILLING OF WHEAT IN RESPONSE TO NITROGEN UNDER LATE- SEASON WATER DEFICIT
}

\author{
ZAVIEH, L. M. ${ }^{1}-$ HADI, H. ${ }^{2 *}-$ SHISHVAN, M. T. ${ }^{3}-$ REZAEI, M. ${ }^{4}$ \\ ${ }^{I}$ Department of Agronomy, Faculaty of Agriculture, Urmia University, Urmia, Iran \\ (tel: +98-44-3367-1651; e-mail: leylamavadat@yahoo.com) \\ ${ }^{2}$ Department of Agronomy, Faculty of Agriculture, Urmia University, Urmia, Iran \\ (tel: +98-44-3277-9558; mobile: +98-91-4322-4159; e-mail: h.hadi@urmia.ac.ir) \\ ${ }^{3}$ Department of Agronomy, Faculty of Agriculture, Urmia University, Urmia, Iran \\ (tel: +98-44-3277-9558; mobile: +98-91-4341-9825; e-mail: Tajbakhsh@gmail.com) \\ ${ }^{4}$ Seed and Plant Improvement Research Department, West Azarbaijan Agricultural and Natural \\ Resources Research and Education Center, AREEO, Urmia, Iran \\ (mobile: +98-91-4346-1364; fax: +98-44-3262-2221; e-mail: rezaei54@yahoo.com) \\ *Corresponding author \\ e-mail: h.hadi@urmia.ac.ir \\ (Received $15^{\text {th }}$ Sep 2017; accepted $20^{\text {th }}$ Feb 2018)
}

\begin{abstract}
In a two-year field experiment, the assessment of leaves and ears photosynthetic contribution to grain filling in winter wheat genotypes was made under nitrogen fertilizer application and water deficit condition. A split plot factorial experiment was conducted based on randomized complete block design with three replications during 2014 and 2015 growing seasons. Treatments were irrigation levels including full irrigation $\left(\mathrm{I}_{1}\right)$ as control and irrigation withholding at heading stages $\left(\mathrm{I}_{2}\right)$, nitrogen $(120$ $\mathrm{kg} \cdot \mathrm{ha}^{-1}$ ) splitting method into different phonological stages including $20 \mathrm{~kg} \cdot \mathrm{ha}^{-1}$ at sowing and $100 \mathrm{~kg} \cdot \mathrm{ha}^{-1}$ at mid-tillering stage $\left(\mathrm{N}_{1}\right), 20 \mathrm{~kg} \cdot \mathrm{ha}^{-1}$ at sowing, $50 \mathrm{~kg} \cdot \mathrm{ha}^{-1}$ at mid-tillering and $50 \mathrm{~kg} \cdot \mathrm{ha}^{-1}$ at stem elongation stage $\left(\mathrm{N}_{2}\right)$ and $20 \mathrm{~kg} \cdot \mathrm{ha}^{-1}$ at sowing, $50 \mathrm{~kg} \cdot \mathrm{ha}^{-1}$ at mid-tillering and $50 \mathrm{~kg} \cdot \mathrm{ha}^{-1}$ at $50 \%$ of heading stage $\left(\mathrm{N}_{3}\right)$ and four winter bread wheat genotypes including zarrin, Pishgam, Orum, and Mihan. Results showed that water deficit stress decreased the photosynthetic contribution of the flag leaf, ear and leaves below the flag leaf to grain filling, 1000-grain weight, number of grains per ear and seed yield of wheat. Furthermore, ear photosynthetic contribution (EPC) was higher compared to the flag leaf (FLPC) and leaves below the flag leaf (OLPC) to grain filling. Higher grain yield of Mihan and Pishgam genotypes can be associated with more grains per ear, 1000-grain weight and higher photosynthetic contribution of flag leaf and ear to grain filling. Such genotypic and environmentally driven differences were associated with changes in most of the traits. According to the results, partitioning of $\mathrm{N}$ fertilizer application to different phonological times can be a proper tool for increasing wheat yield under water deficit condition on different genotypes.
\end{abstract}

Keywords: grain yield, leaves below flag leaf, nitrogen splitting, phonological stages, water limitation

\section{Introduction}

Wheat is considered as the most important crop grown in the semi-arid regions where water deficit stress seems to be one of the most limiting factors for agricultural products (Maccaferri et al., 2011). That is to say, such a strategic crop usually suffers from water deficit stress during grain-filling period affecting the yield of the plant. According to Maccaferri et al. (2011), the reaction and response of plants to water deficit are evaluated based on genetic, biochemical, and morpho-physiological features of a plant. 
The variations in the crop on the water uptake capacity during or shortly before the post-anthesis phase can have major effects on grain yield because growing grain number and grain weight are set during this stage.

Final grain weight is in relation to the duration of grain filling period and rate, and the respective interaction in-between (Sadras and Egli, 2008). In C3 cereals, such as wheat and barley, grain filling process is determined by current photosynthesis of the upper parts of the plant, i.e. both the flag leaf and the ear (Tambussi et al., 2007) and by redistribution of assimilates stored in the stem (Ehdaie et al., 2008). Further, the leaf photosynthesis value is affected by the position of the leaf on the plant. The flag leaf and the second leaf are the most active leaves in the photosynthesis rate in the wheat (Olszewski et al., 2008). According to Maydup et al. (2010) ear, photosynthesis plays a key role in the grain yield of wheat under both stress and non-stress conditions.

$\mathrm{N}$ in the plant is in the structure of the protein and nucleic acids, which are the most important building and information substances of every cell. In addition, $\mathrm{N}$ is also found in chlorophyll enabling the plant to transfer energy from sunlight through the process of photosynthesis. So, the value of $\mathrm{N}$ supply to the plant will influence the amount of protein, amino acids, protoplasm, and chlorophyll formed. Moreover, it influences cell size, leaf area, and photosynthetic activity (Uribelarrea et al., 2009; Diacono et al., 2013). Dordas et al. (2008) reported that higher rates of $N$ increase photosynthetic processes, leaf area production, leaf area duration as well as grain filling period. Lawrence et al. (2008) also reported that the reduction in photosynthesis caused by drought occurs more in the lower leaves than in the upper ones, and this reduction also was reported to be lower in the ear compared to the leaves. In the same line, under low nitrogen supply, plants use photosynthesis to maintain life functions which are not related to the yield-forming process. Under high nitrogen supply, the photosynthetic activity of ears causes the grain yield to increase (Olszewski et al., 2008). Soleymani fard and Sidat (2011) suggested that yield and yield components of safflower are increased by increasing the rate of applied nitrogen.

A better understanding of growth parameters may of help in programs the objective of which is to improve the grain yield under water limitation. Determination of response of wheat to $\mathrm{N}$ application is very important to maximize yield and economic profitability of wheat production in a particular environment. Considering the abovementioned facts, the present study was undertaken to know the effects of nitrogen rates on growth parameters and yield quantity of wheat under drought stress.

\section{Material and methods}

The field experiment was conducted as split factorial plot based on randomized complete block design with three replications during 2013-2014 and 2014-2015 growing seasons in the agriculture research station of Miandoab in West Azarbayjan province, Iran. The area is located at $\left(46^{\circ} 6^{\prime} \mathrm{N}\right.$ latitude and $36^{\circ} 58^{\prime} \mathrm{E}$ longitude; alt. $1143 \mathrm{~m}$, Miandoab, West Azarbaijan Province, Iran). Climatically, the area is placed in a semi-arid temperate zone with a pretty cold winter and a hot summer. The mean temperature and precipitation wheat growing season in 2014-2015 are presented in Figure 1.

In the field of the present study, each plot was included 6 rows with 4-m long. Besides, plots and blocks were separated by $3 \mathrm{~m}$ unplanted distances. The wheat cultivars were sown with a density of 400 seeds per $\mathrm{m}^{2}$. Regarding the treatments, irrigation levels were set as the variables of the investigation where Full Irrigation (I1) was considered as 
control while Irrigation Withholding during heading stages (I2), in main plots and the time of the application of nitrogen fertilizer and varieties were allocated to subplots as the treatments. Based on the results of the meteorological station located at the site of the experiment and collecting the meteorological data, amount of water were determined according to evaporation from class A pan and, using relevant calculations, the water volume required for irrigation was determined. To irrigate the volume of irrigation water in the plots, a pressure meter and pressurized water pipes were used to maintain the water volume consumed per plot in accordance with the evaporation rate of $100 \mathrm{~mm}$ evaporation from class A pan. Thus, the volume of water consumed for each round was about $650 \mathrm{~m}^{3} / \mathrm{ha}$. Furthermore, Nitrogen fertilizer, $120 \mathrm{~kg}$ in total, was applied in three different arrangements as follow: $20 \mathrm{~kg} \cdot \mathrm{ha}^{-1}$ nitrogen fertilizer in sowing and $100 \mathrm{~kg} \cdot \mathrm{ha}^{-1}$ at mid-tillering stage (N1), $20 \mathrm{~kg} \cdot \mathrm{ha}^{-1}$ nitrogen fertilizer in sowing, $50 \mathrm{~kg} \cdot \mathrm{ha}^{-1}$ at midtillering and $50 \mathrm{~kg} \cdot \mathrm{ha}^{-1}$ at stem elongation stage (N2), and $20 \mathrm{~kg} \cdot \mathrm{ha}^{-1}$ nitrogen fertilizer in sowing, $50 \mathrm{~kg} \cdot \mathrm{ha}^{-1}$ at mid-tillering and $50 \mathrm{~kg} \cdot \mathrm{ha}^{-1}$ at $50 \%$ of heading stage (N3). In regard to the type of the varieties, four genotypes of winter bread wheat, Zarrin, Pishgam, Orum, and Mihan were utilized in the study.

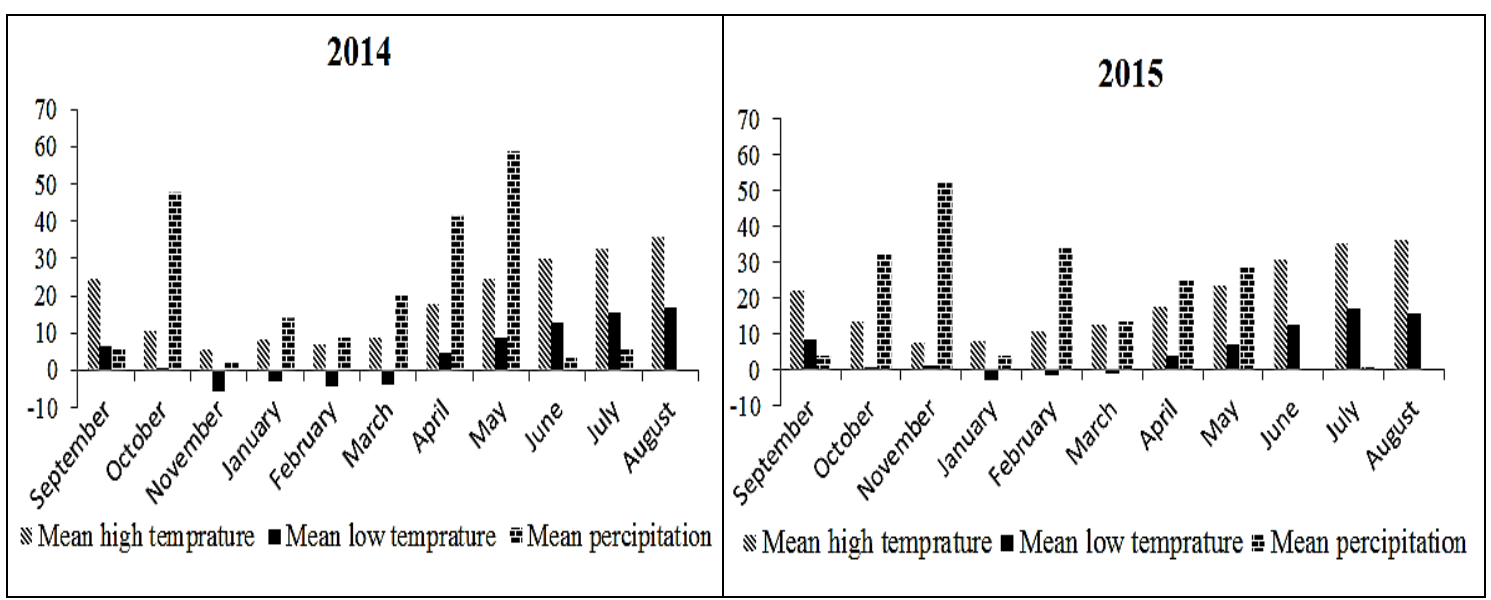

Figure 1. Mean temperature and precipitation wheat growing season at 2014-2015

Irrigation, weeding, and all other agronomic practices except those under study were kept consistent and uniform for all treatments. The soil samples were taken from the $30 \mathrm{~cm}$ depth of surface soil with soil auger 20 days before the beginning of the experiment in both formerly mentioned growing seasons. Moreover, the physicochemical properties of the soil samples have analyzed the result of which are presented in Table 1.

Table 1. Soil physico-chemical properties at depth of $0-30 \mathrm{~cm}$

\begin{tabular}{c|c|c|c|c|c|c|c}
\hline $\begin{array}{c}\text { K available } \\
\text { (p.p.m) }\end{array}$ & $\begin{array}{c}\text { P available } \\
\text { (p.p.m) }\end{array}$ & N total (\%) & O.C. (\%) & Texture & pH & $\begin{array}{c}\text { Depth of } \\
\text { sampling (cm) }\end{array}$ & Year \\
\hline 255 & 8.05 & 0.13 & 0.78 & Silty-loam & 8 & $0-30$ & 2014 \\
180 & 8.4 & 0.9 & 0.61 & Silty-loam & 9 & $0-30$ & 2015 \\
\hline
\end{tabular}


Some physiological traits were determined for the measurement of growth parameters. In the first sampling procedures, ten samples were taken at flowering stages in both time periods. In order to determine the weight of spike, peduncle, and internode, the samples were dried in an oven for $48 \mathrm{~h}$ at $80^{\circ} \mathrm{C}$. Then, the samples were treated for determining the phenotypic manipulations components. This was followed by the removal of all the leaves below the flag leaf, the flag leaf, and half of the spike. At the maturity stage, both labeled plants and 10 other randomly selected plants were harvested to determine the yield components and traits such as total dry matter, ear weight, grain weight per ear, and grain number per ear, 1000-grain weight and seed yield. Then the photosynthetic contributions of different plant parts (ear, flag leaf and leaves below the flag leaf) to grain filling in bread wheat genotypes were calculated as follows:

$$
\begin{gathered}
\mathrm{EPC}=(\text { ear weight in flowering }-(\text { ear weight in physiological maturity }- \text { ear grain } \\
\text { weight })) / \text { grain yield }
\end{gathered}
$$

FLPC $=($ ear grain weight - ear grain weight in flag leaf removal plant $) /$ grain yield

OLPC $=($ ear grain weight - ear grain weight in other leaf removal plant $) /$ grain yield

where EPC, FLPC, and BFLPC refer to photosynthetic contributions of the ear, flag leaf and leaves below the flag leaf to grain filling, respectively.

The analysis of variance for the collected data was calculated applying SAS software a the main effects and interactions were tested using the Duncan's multiple range tests $(\mathrm{p} \leq 0.05)$.

\section{Results and discussion}

The results obtained from the combined (two-year data) analysis of variance, showed a significant effect of the interaction $\mathrm{I} \times \mathrm{N} \times \mathrm{G}$ on photosynthetic contribution of the flag-leaf to grain filling, photosynthetic contribution of the ear to grain filling and number of grains per-ear in wheat plants in the field condition (Table 2). It was also revealed that the interaction of $\mathrm{Y} \times \mathrm{I} \times \mathrm{N} \times \mathrm{G}$ significantly affects the photosynthetic contribution of the leaves below the flag-leaf to grain filling and 1000-grain weight (Table 2). The photosynthetic contribution of the ear to grain filling was affected by the interaction of $\mathrm{Y} \times \mathrm{I} \times \mathrm{N}$ (Table 2). Furthermore, the number of grains per ear and grain yield also were affected by the interaction of $\mathrm{Y} \times \mathrm{I} \times \mathrm{G}$ (Table 2). The findings also showed that the number of grains per ear can be affected by the interaction of $\mathrm{Y} \times \mathrm{N} \times$ $\mathrm{G}$ (Table 2).

\section{Photosynthetic contribution of the flag leaf to grain filling}

As Amiri et al. (2013) stated in their article, due to the proximity of Flag-leaf to the spike, and the longer green life of it, the photosynthetic contribution of the flag-leaf is one of the most important sources for higher grain yield production during grain filling period. In this study, the highest photosynthetic contribution of the flag-leaf to grain filling (18.48\%) was observed in Pishgaam genotype G2 (I1N2G2) under normal irrigation condition as $\mathrm{I} 1$ and the application of $\mathrm{N} 2$ (Table 3) . The lowest value $(10.22 \%)$ was obtained at I2N3G1 (Table 3). 
Our results also showed that among the studied genotypes, Pishgaam genotype had the highest contribution of the flag-leaf to grain filling. Such results suggested that the flag-leaf contribution depends not only on sink strength but also on genotypic variations. In this line, the increase in the assimilate production was linked to the long green life of flag-leaf. N2 fertilizer treatments increased the photosynthetic contribution of the flag-leaf compared to the other nitrogen treatments. Low photosynthesis under water deficit stress was reported to be the result of lower chlorophyll synthesis and higher chlorophyll breakdown (Osman, 2014). Chlorophyll loss can also be due to damage to mesophyll chloroplasts leading to a lower photosynthetic rate (Wang and Xiao, 2009). The importance of the flag leaf in determining the mean grain weight, at mid-tillering and stem elongation of the plant is well-known. Sanjeri et al. (2008) showed that in water deficit condition, chlorophyll content of wheat genotypes decrease and this reduction is significant among genotypes.

Table 2. Summary of the analysis of variance for all the analyzed parameters

\begin{tabular}{|c|c|c|c|c|c|c|c|}
\hline \multirow[b]{2}{*}{$\begin{array}{l}\text { Source of } \\
\text { variation }\end{array}$} & \multirow[b]{2}{*}{ Df } & \multicolumn{6}{|c|}{ Mean square } \\
\hline & & $\begin{array}{l}\text { Photosynthetic } \\
\text { contribution } \\
\text { of the flag leaf } \\
\text { to grain filling }\end{array}$ & $\begin{array}{c}\text { Photosynthetic } \\
\text { contribution } \\
\text { of the leaves } \\
\text { below the flag } \\
\text { leaf to grain } \\
\text { filling }\end{array}$ & $\begin{array}{c}\text { Photosynthetic } \\
\text { contribution } \\
\text { of the ear to } \\
\text { grain filling }\end{array}$ & $\begin{array}{c}\text { 1000- } \\
\text { grain } \\
\text { weight }\end{array}$ & $\begin{array}{c}\text { Number } \\
\text { of grains } \\
\text { per ear }\end{array}$ & Grain yield \\
\hline Year (Y) & 1 & $71.30^{*}$ & $752.03 * *$ & $1428.21 *$ & $25.84 \mathrm{~ns}$ & $1936.000 *$ & $21834592.56^{* * *}$ \\
\hline Replication/year & 4 & 22.38 & 3.18 & 220.20 & 60.31 & 204.97 & 1693022.33 \\
\hline Irrigation (I) & 1 & $0.001 \mathrm{~ns}$ & $64.34 * *$ & $173.27 \mathrm{~ns}$ & $770.06^{* *}$ & $26.69 \mathrm{~ns}$ & $151850167.56^{* *}$ \\
\hline $\mathrm{I} \times \mathrm{Y}$ & 1 & $56.163 *$ & $148.88 * *$ & 461.10ns & $189.06 \mathrm{~ns}$ & $38.02 \mathrm{~ns}$ & $72061706.174 * *$ \\
\hline Error a & 4 & 8.45 & 2.65 & 153.20 & 13.292 & 116.52 & 43517.13 \\
\hline Nitrogen $(\mathrm{N})$ & 2 & $58.31 * *$ & $4.33 \mathrm{~ns}$ & $1.83 \mathrm{~ns}$ & $69.71 * *$ & $521.69 * *$ & $5594760.43^{* *}$ \\
\hline $\mathrm{Y} \times \mathrm{N}$ & 2 & $18.20 \mathrm{~ns}$ & $61.10 * *$ & $6.96 \mathrm{~ns}$ & $60.007 *$ & $40.58 \mathrm{~ns}$ & $164618.77 \mathrm{~ns}$ \\
\hline $\mathrm{I} \times \mathrm{N}$ & 2 & $36.96^{*}$ & $0.60 \mathrm{~ns}$ & $24.45 \mathrm{~ns}$ & $5.81 \mathrm{~ns}$ & $57.69 \mathrm{~ns}$ & $960658.56 \mathrm{~ns}$ \\
\hline $\mathrm{Y} \times \mathrm{I} \times \mathrm{N}$ & 2 & $3.31 \mathrm{~ns}$ & $42.97 *$ & $115.12 *$ & $30.271 \mathrm{~ns}$ & $44.19 \mathrm{~ns}$ & $60796.75 \mathrm{~ns}$ \\
\hline Genotype (G) & 3 & $97.49 * *$ & $33.07 *$ & $113.34 *$ & $215.80 * *$ & $150.74 \mathrm{~ns}$ & $44327283.563 * *$ \\
\hline $\mathrm{Y} \times \mathrm{G}$ & 3 & $67.30 * *$ & $37.92 *$ & $13.71 \mathrm{~ns}$ & $34.35 *$ & $436.88 * *$ & $2116660.50 * *$ \\
\hline $\mathrm{I} \times \mathrm{G}$ & 3 & $8.46 \mathrm{~ns}$ & $19.51 \mathrm{~ns}$ & $6.62 \mathrm{~ns}$ & $19.87 \mathrm{~ns}$ & $51.65 \mathrm{~ns}$ & $1299497.581 *$ \\
\hline $\mathrm{Y} \times \mathrm{I} \times \mathrm{G}$ & 3 & $20.98 \mathrm{~ns}$ & $11.67 \mathrm{~ns}$ & $34.45 \mathrm{~ns}$ & $8.17 \mathrm{~ns}$ & $232.17 *$ & $7220776.007 * *$ \\
\hline $\mathrm{N} \times \mathrm{G}$ & 6 & $10.13 \mathrm{~ns}$ & $14.20 \mathrm{~ns}$ & $80.92 *$ & $38.87 * *$ & $22.04 \mathrm{~ns}$ & $908637.41 *$ \\
\hline $\mathrm{Y} \times \mathrm{N} \times \mathrm{G}$ & 6 & $4.81 \mathrm{~ns}$ & $27.08 *$ & $28.70 \mathrm{~ns}$ & $3.55 \mathrm{~ns}$ & $144.47 *$ & $255124.24 \mathrm{~ns}$ \\
\hline $\mathrm{I} \times \mathrm{N} \times \mathrm{G}$ & 6 & $28.92 *$ & $0.20 \mathrm{~ns}$ & $71.51 *$ & $8.65 \mathrm{~ns}$ & $189.60 *$ & $162713.22 \mathrm{~ns}$ \\
\hline $\mathrm{Y} \times \mathrm{I} \times \mathrm{N} \times \mathrm{G}$ & 6 & $16.38 \mathrm{~ns}$ & $49.71 * *$ & $21.10 \mathrm{~ns}$ & $43.24 * *$ & $28.00 \mathrm{~ns}$ & $138935.28 \mathrm{~ns}$ \\
\hline Error b & 88 & 10.82 & 11.44 & 46.29 & 12.54 & 64.87 & 426042.78 \\
\hline C.V. & & 14.55 & 13.22 & 14.28 & 9.95 & 13.55 & 9.73 \\
\hline
\end{tabular}

ns: not significant at $P \leq 0.05 ; *$ : significant at $P \leq 05 ; * *$ : significant at $P \leq 01$

\section{Photosynthetic contribution of the ear to grain filling}

In the present study, in terms of grain filling, in all wheat genotypes, treatments, the time of nitrogen fertilizer application, and water deficit conditions, the photosynthetic contribution of the ear was better than the flag-leaf. The highest photosynthetic 
contribution of the ear to grain filling $(35.08 \%)$ was observed in normal irrigation as I1, application of N3, and Mihan genotype as G4 (I1N3G4) (Table 3). The lowest value $(21.52 \%)$ of the photosynthetic contribution of the ear to grain filling was obtained at I2N2G2 (Table 3).

Table 3. Comparison of means for the experimental factors including genotypes and nitrogen application on photosynthetic contribution of the ear and flag leaf to grain filling

\begin{tabular}{|c|c|c|c|c|c|c|c|c|c|}
\hline \multicolumn{2}{|c|}{ Treatment } & \multicolumn{4}{|c|}{$\begin{array}{c}\text { Photosynthetic contribution of the flag } \\
\text { leaf to grain filling }(\%)\end{array}$} & \multicolumn{4}{|c|}{$\begin{array}{c}\text { Photosynthetic contribution of the ear } \\
\text { to grain filling }(\%)\end{array}$} \\
\hline $\begin{array}{l}\text { Water } \\
\text { limitation }\end{array}$ & $\begin{array}{c}\text { Nitrogen } \\
\text { application }\end{array}$ & G1 & G2 & G3 & G4 & G1 & G2 & G3 & G4 \\
\hline \multirow{3}{*}{ I1 } & N1 & $11.23 \mathrm{cde}$ & $12.28 \mathrm{~b}-\mathrm{e}$ & $11.56 \mathrm{cde}$ & $13.12 b-e$ & 27.73a-d & $25.21 \mathrm{~b}-\mathrm{d}$ & $33.71 \mathrm{ab}$ & $27.48 \mathrm{a}-\mathrm{d}$ \\
\hline & $\mathrm{N} 2$ & $13.22 \mathrm{~b}-\mathrm{e}$ & $18.48 \mathrm{a}$ & $12.40 \mathrm{~b}-\mathrm{e}$ & $18.44 \mathrm{a}$ & 28.18a-d & $27.04 \mathrm{a}-\mathrm{d}$ & $30.73 a-d$ & $28.64 a-d$ \\
\hline & N3 & $10.44 \mathrm{e}$ & $12.21 \mathrm{~b}-\mathrm{e}$ & $13.57 \mathrm{~b}-\mathrm{e}$ & $14.08 \mathrm{~b}-\mathrm{e}$ & $23.99 \mathrm{~cd}$ & $32.32 \mathrm{abc}$ & $29.25 \mathrm{a}-\mathrm{d}$ & $35.08 \mathrm{a}$ \\
\hline \multirow{3}{*}{$\mathrm{I} 2$} & N1 & $12.74 \mathrm{~b}-\mathrm{e}$ & $16.68 \mathrm{ab}$ & $11.28 \mathrm{cde}$ & $13.51 \mathrm{~b}-\mathrm{e}$ & $26.33 \mathrm{a}-\mathrm{d}$ & $29.19 a-d$ & $26.43 \mathrm{a}-\mathrm{d}$ & $26.98 \mathrm{a}-\mathrm{d}$ \\
\hline & N2 & $11.13 \mathrm{cde}$ & $15.34 \mathrm{a}-\mathrm{d}$ & $15.48 \mathrm{a}-\mathrm{d}$ & $12.87 \mathrm{~b}-\mathrm{e}$ & $24.88 \mathrm{bcd}$ & $21.52 \mathrm{~d}$ & $30.70 a-d$ & $31.72 \mathrm{abc}$ \\
\hline & N3 & $10.22 \mathrm{~b}-\mathrm{e}$ & $14.49 \mathrm{a}-\mathrm{e}$ & $11.06 \mathrm{de}$ & $15.71 \mathrm{abc}$ & $23.23 \mathrm{~cd}$ & $29.83 a-d$ & $26.50 \mathrm{a}-\mathrm{d}$ & $25.72 a-d$ \\
\hline
\end{tabular}

Means in each column followed by similar letter(s) are not significantly different at $5 \%$ probability level, using Duncan's Multiple Range Test

I1 and I2 indicate normal irrigation and irrigation withholding in heading stages. N1, N2 and N3 indicate (20 kg.ha ${ }^{-1}$ nitrogen fertilizer in sowing and $100 \mathrm{~kg} \cdot \mathrm{ha}^{-1}$ at mid tillering stage), $\left(20 \mathrm{~kg} \cdot \mathrm{ha}^{-1}\right.$ nitrogen fertilizer in sowing, $50 \mathrm{~kg} \cdot \mathrm{ha}^{-1}$ at mid tillering and $50 \mathrm{~kg} \cdot \mathrm{ha}^{-1}$ at stem elongation stage) and $\left(20 \mathrm{~kg} \cdot \mathrm{ha}^{-1}\right.$ nitrogen fertilizer in sowing, $50 \mathrm{~kg} \cdot \mathrm{ha}^{-1}$ at mid tillering and $50 \mathrm{~kg} \cdot \mathrm{ha}^{-1}$ at $50 \%$ of heading stage) respectively

G1, G2, G3 and G4 indicate Zarrin, Peshgam, Orum and Mihan genotypes respectively

According to the findings of the present investigation, the photosynthetic contribution of the ear to grain filling varied from $21 \%$ to $35 \%$. Nonetheless, under water deficit conditions, the photosynthetic contribution of the ear in all genotypes was not significant (Table 5). According to a comparable study run by Mydup et al. (2010), the ear photosynthetic may act as a buffer in preventing serious damages under water deficit condition. Probably this can mainly be attributed to high durability of ear photosynthesis and the close relationship between grain and the ear. Considering the fact that ear benefits from a long-term spike photosynthetic activity with awn, the photosynthetic contribution of the ear is greater (Amiri et al., 2013). The decreased photosynthesis of the plant under water-stressed could be explained by the stomatal closure, which reduces CO2 diffusion. Abebe et al. (2003) indicated that an early decrease in the photosynthesis during drought season is due to an increase in stomatal resistance. The Study conducted in the years 2014-2015, showed that maximum photosynthetic contribution of the ear $(32.50 \mathrm{~g})$ was obtained in Y2I2N2 (Table 4), whereas the minimum value (20.33 g) was observed in Y1I2N3 (Table 6). In 2015, due largely to a good agronomical condition, the photosynthetic contribution of the ear to grain filling increased up to $58 \%$, which was higher considering the application of N3I2 in the same year (Table 4). These results indicated that the ear, as a photosynthetic organ, is better adapted than the flag-leaf to environmental factors. Even under good agronomical conditions, the ear may be more important than the flag-leaf during grain filling (Tambussi et al., 2007). 
Table 4. Comparison of means for the experimental factors including genotypes and water limitation on photosynthetic contribution of the ear to grain filling of wheat under water limitation in two years, 2014-2015

\begin{tabular}{c|c|c|c|c}
\hline \multicolumn{2}{|c|}{ Treatment } & \multicolumn{3}{c}{ Photosynthetic contribution of the ear to grain filling (\%) } \\
\hline Year & Water limitation & $\mathbf{N}_{\mathbf{1}}$ & $\mathbf{N}_{\mathbf{2}}$ & $\mathbf{N}_{\mathbf{3}}$ \\
\hline \multirow{2}{*}{$\mathrm{Y}_{1}=2014$} & $\mathrm{I}_{1}$ & $25.02 \mathrm{bcd}$ & $28.42 \mathrm{abc}$ & $29.82 \mathrm{abc}$ \\
& $\mathrm{I}_{2}$ & $23.70 \mathrm{~cd}$ & $21.91 \mathrm{~d}$ & $20.33 \mathrm{~d}$ \\
\hline \multirow{2}{*}{$\mathrm{Y}_{2}=2015$} & $\mathrm{I}_{1}$ & $32.05 \mathrm{a}$ & $28.87 \mathrm{abc}$ & $30.50 \mathrm{ab}$ \\
& $\mathrm{I}_{2}$ & $30.77 \mathrm{ab}$ & $32.50 \mathrm{a}$ & $32.31 \mathrm{a}$ \\
\hline
\end{tabular}

Means in each column followed by similar letter(s) are not significantly different at $5 \%$ probability level, using Duncan's Multiple Range Test

I1 and I2 indicate normal irrigation and irrigation withholding in heading stages. N1, N2 and N3 indicate $\left(20 \mathrm{~kg} \cdot \mathrm{ha}^{-1}\right.$ nitrogen fertilizer in sowing and $100 \mathrm{~kg} \cdot \mathrm{ha}^{-1}$ at mid tillering stage), (20 kg.ha ${ }^{-1}$ nitrogen fertilizer in sowing, $50 \mathrm{~kg} \cdot \mathrm{ha}^{-1}$ at mid tillering and $50 \mathrm{~kg} \cdot \mathrm{ha}^{-1}$ at stem elongation stage) and (20 $\mathrm{kg} \cdot \mathrm{ha}^{-1}$ nitrogen fertilizer in sowing, $50 \mathrm{~kg} \cdot \mathrm{ha}^{-1}$ at mid tillering and $50 \mathrm{~kg} \cdot \mathrm{ha}^{-1}$ at $50 \%$ of heading stage) respectively

\section{The photosynthetic contribution of the leaves below the flag leaf to grain filling}

It was well-established that the flag leaf and the ear are not the only sources of assimilates to grain filling (Tambussi et al., 2007). This study reported that the photosynthetic contribution of the ear was greater than that of the flag leaf and the leaves below the flag leaf. Owning to a good environmental condition in 2014 compared to the same period in 2015, among all genotypes, the photosynthetic contribution of the leaves below the flag leaf to grain filling was higher, and the photosynthetic contribution of the other leaves to grain filling was lower in Mihan genotype largely due to the lower height of the plants (Table 5). Indeed, the effect of the photosynthetic contribution to grain filling of flag leaf is an important parameter to assess rather than the leaves below flag leaf. The results showed that the maximum photosynthetic contribution of the leaves below the flag leaf to grain filling $(19.45 \%)$ was obtained in Y1I2N2G1 (Table 5). But the lowest value $(3.25 \%)$ was observed in Y2I2N3G4 (Table 5).

\section{0-kernel weight}

Grain yield in wheat is the result of the number of grains per ear and grain weight (Ahmad et al., 1988). Some studies in 2013-2014 showed that a maximum of 1000grain weight $(53.33 \mathrm{~g})$ was obtained in Y1I1N3G4 and Y1I1N2G4 (Table 5). But the minimum value (33.33 g) was observed in Y1I2N3G1 (Table 5). Mihan and Pishgaam genotypes were higher 1000-kernel weight under water deficit condition. In 2014 under water deficit condition, 1000-kernel weight decreased about $22 \%$ in I1N3G4 compared to I2N3G4 (Table 5). It seems that the environmental factors have a high influence on the 1000-kernel weight, and this trait, especially in 2015, is significantly affected by water deficit and nitrogen fertilizer division. These results are in line with the results of the study practiced by Ahmadi et al. (2006). Akinirinde (2006) and Alam et al. (2007) reported that the increase in 1000-kernel weight resulted from the increase in the photosynthesis. In the present study, the photosynthetic contribution of the leaves, flag leaf, and ear during grain filling period could correlate with grain yield. Azarpanah et al. 
(2013) stated that the reduction of crop yield is related to the reduction of rate and amount of photosynthesis and thousand seeds weight.

Table 5. Comparison of means for the experimental factors including genotypes and nitrogen application on thousand grain weight and photosynthetic contribution of the leaves below the flag leaf to grain filling of wheat under water limitation in two years, 2014-2015

\begin{tabular}{|c|c|c|c|c|c|c|c|c|c|c|}
\hline & \multicolumn{2}{|c|}{ Treatment } & \multicolumn{4}{|c|}{ 1000-grain weight $(\mathrm{g})$} & \multicolumn{4}{|c|}{$\begin{array}{l}\text { Photosynthetic contribution of the } \\
\text { leaves below the flag leaf to grain } \\
\text { filling }(\%)\end{array}$} \\
\hline Year & $\begin{array}{c}\text { Water } \\
\text { limitation }\end{array}$ & \begin{tabular}{|c|} 
Nitrogen \\
application
\end{tabular} & $\mathbf{G}_{\mathbf{1}}$ & $\mathbf{G}_{2}$ & $\mathbf{G}_{3}$ & $\mathbf{G}_{4}$ & $\mathbf{G}_{\mathbf{1}}$ & $\mathbf{G}_{2}$ & $\mathbf{G}_{3}$ & $\mathbf{G}_{\mathbf{4}}$ \\
\hline \multirow{6}{*}{$Y_{1}=2014$} & \multirow{3}{*}{$\mathrm{I}_{1}$} & $\mathrm{~N}_{1}$ & $41.67 f-n$ & $45.33 \mathrm{c}-\mathrm{k}$ & 48.33a-g & 48.67a-f & $14.56 \mathrm{a}-\mathrm{g}$ & $17.59 \mathrm{abc}$ & $13.14 a-j$ & $10.59 \mathrm{c}-1$ \\
\hline & & $\mathrm{N}_{2}$ & $44 d-1$ & $51.67 \mathrm{abc}$ & $49.33 a-d$ & $53.33 \mathrm{a}$ & 14.90a-e & $14.67 \mathrm{a}-\mathrm{f}$ & $14.65 \mathrm{a}-\mathrm{f}$ & $14.51 \mathrm{a}-\mathrm{g}$ \\
\hline & & $\mathrm{N}_{3}$ & $45.33 \mathrm{c}-\mathrm{k}$ & $53.00 \mathrm{ab}$ & $47.00 \mathrm{a}-\mathrm{i}$ & $53.33 \mathrm{a}$ & 18.19ab & $16.80 \mathrm{a}-\mathrm{d}$ & $10.24 \mathrm{~d}-\mathrm{m}$ & $13.47 \mathrm{a}-\mathrm{j}$ \\
\hline & \multirow{3}{*}{$\mathrm{I}_{2}$} & $\mathrm{~N}_{1}$ & 35.67 no & $41.67 \mathrm{f}-\mathrm{n}$ & $41.33 g-n$ & $39.00 \mathrm{k}-\mathrm{o}$ & $8.007 \mathrm{f}-\mathrm{n}$ & $11.43 \mathrm{c}-1$ & $6.81 \mathrm{j}-\mathrm{n}$ & $8.99 \mathrm{e}-\mathrm{n}$ \\
\hline & & $\mathrm{N}_{2}$ & $41.67 f-n$ & $43.67 d-1$ & $42.67 \mathrm{~d}-\mathrm{m}$ & $45.67 \mathrm{c}-\mathrm{k}$ & $19.45 \mathrm{a}$ & $10.87 \mathrm{c}-1$ & $13.33 a-j$ & 7.50h-n \\
\hline & & $\mathrm{N}_{3}$ & 33.330 & 46.67a-j & $45.33 \mathrm{c}-\mathrm{k}$ & $41.33 \mathrm{~g}-\mathrm{n}$ & 14.70a-h & $12.23 \mathrm{~b}-\mathrm{k}$ & $11.89 \mathrm{~b}-1$ & 8.61e-n \\
\hline \multirow{6}{*}{$Y_{2}=2015$} & \multirow{3}{*}{$\mathrm{I}_{1}$} & $\mathrm{~N}_{1}$ & $42.00 \mathrm{e}-\mathrm{n}$ & $44.67 \mathrm{c}-1$ & 49.00a-e & 47.00a-i & 7.13i-n & $7.12 \mathrm{i}-\mathrm{n}$ & $5.90 \mathrm{k}-\mathrm{n}$ & $11.60 \mathrm{~b}-1$ \\
\hline & & $\mathrm{N}_{2}$ & $46.67 a-j$ & $43.33 \mathrm{~d}-\mathrm{m}$ & $43.33 \mathrm{~d}-\mathrm{m}$ & $46.00 \mathrm{~b}-\mathrm{k}$ & $12.46 \mathrm{~b}-\mathrm{k}$ & $7.41 \mathrm{~h}-\mathrm{n}$ & $5.76 \mathrm{k}-\mathrm{n}$ & $7.72 \mathrm{~g}-\mathrm{n}$ \\
\hline & & $\mathrm{N}_{3}$ & $36.33 \mathrm{mno}$ & $47.67 \mathrm{a}-\mathrm{h}$ & 48.67a-f & $48.67 \mathrm{a}-\mathrm{f}$ & $3.96 \mathrm{mn}$ & $7.81 \mathrm{f}-\mathrm{n}$ & $10.15 \mathrm{~d}-\mathrm{m}$ & 7.34h-n \\
\hline & \multirow{3}{*}{$\mathrm{I}_{2}$} & $\mathrm{~N}_{1}$ & 43.33d-m & $39.67 \mathrm{j}-\mathrm{o}$ & $43.67 \mathrm{~d}-1$ & $40.33 \mathrm{i}-\mathrm{n}$ & $10.82 \mathrm{c}-1$ & $11.42 \mathrm{c}-1$ & 13.93a-i & $7.83 \mathrm{f}-\mathrm{n}$ \\
\hline & & $\mathrm{N}_{2}$ & 37.671-o & $40.67 \mathrm{~h}-\mathrm{n}$ & $44.67 \mathrm{c}-1$ & $43.00 \mathrm{~d}-\mathrm{m}$ & $5.261 \mathrm{mn}$ & $9.03 \mathrm{e}-\mathrm{n}$ & $5.70 \mathrm{k}-\mathrm{n}$ & 9.90e-n \\
\hline & & $\mathrm{N}_{3}$ & 43.00d-m & 46.67a-j & $45.67 \mathrm{c}-\mathrm{k}$ & $47.00 \mathrm{a}-\mathrm{i}$ & $7.02 \mathrm{j}-\mathrm{n}$ & $8.39 \mathrm{e}-\mathrm{n}$ & $10.19 \mathrm{~d}-\mathrm{m}$ & $3.25 n$ \\
\hline
\end{tabular}

Means in each column followed by similar letter(s) are not significantly different at $\%$ probability level, using Duncan's Multiple Range Test

$I_{1}$ and $I_{2}$ indicate normal irrigation and irrigation withholding in heading stages. $N_{1}, N_{2}$ and $N_{3}$ indicate $\left(20 \mathrm{~kg} \cdot \mathrm{ha}^{-1}\right.$ nitrogen fertilizer in sowing and $100 \mathrm{~kg} \cdot \mathrm{ha}^{-1}$ at mid tillering stage), $\left(20 \mathrm{~kg} \cdot \mathrm{ha}^{-1}\right.$ nitrogen fertilizer in sowing, $50 \mathrm{~kg} \cdot \mathrm{ha}^{-1}$ at mid tillering and $50 \mathrm{~kg} \cdot \mathrm{ha}^{-1}$ at stem elongation stage) and $\left(20 \mathrm{~kg} \cdot \mathrm{ha}^{-1}\right.$ nitrogen fertilizer in sowing, $50 \mathrm{~kg} \cdot \mathrm{ha}^{-1}$ at mid tillering and $50 \mathrm{~kg} \cdot \mathrm{ha}^{-1}$ at $50 \%$ of heading stage) respectively. $\mathrm{G}_{1}, \mathrm{G}_{2}, \mathrm{G}_{3}$ and $\mathrm{G}_{4}$ indicate Zarrin, Peshgam, Orum and Mihan genotypes respectively

\section{The number of grains ear}

The number of grain ears is an important factor that affects the grain yield in wheat (Wei-Wei et al., 2012). The comparison of the effects of the interaction means of rates and time of $\mathrm{N}$ application and genotypes on the number of grains per ear in 2014 and 2015 indicated that the highest value (73.67) belonged to Y2N2G4, and the minimum number of grains per ear (45.50) was recorded at Y1N3G3 (Table 6). The highest number of grains per ear (66.83) was recorded at limited irrigation, application of N2 and Orum genotype (I2N2G3), and the lowest values of this trait (50.83) were recorded at I2N3G1 treatments (Table 7). The maximum number of grains per ear (70.11) was recorded at Orum genotype in normal irrigation condition in 2015 as Y2I1G3, and the minimum of this trait was recorded at Orum genotype and water limitation in 2014 as Y1I2G3 treatment (Table 8).

This reduction was probably due to the reduction of the numbers of the endosperm cells leading to the reduction of sink strength. This, in turn, could confer a critical survival advantage for few versus many seeds in terminal drought environments by reducing sink numbers at a key point in development and thus secure a sufficient sucrose supply for maturation of a few remaining seeds as observed under irrigation conditions. This is supported by a previous report showing that $180 \mathrm{~kg} \cdot \mathrm{ha}^{-1}$ urea increased significantly the number of grains per head in safflower (Seyed Sharifi, 2011). 
Dawadi and Sah (2012) suggested that a decrease in the number of grains per ear under lower $\mathrm{N}$ fertilizer application at stem elongation might be attributed to the poor development of sinks and the reduction of t photosynthates translocation. In this study, high $\mathrm{N}$ rates increased the photosynthesis and delayed the appearance of phenological stages. It seems that high $\mathrm{N}$ rate can be one of the reasons of increasing the number of grains per ear row. Similar results have been reported by Alam and Haidar (2006). Increase in the number of grains per ear at higher $\mathrm{N}$ rates might be due to the lower competition for the nutrients allow the plants to accumulate more biomass with higher capacity to convert more photosynthesis into sinks (Zeidan et al., 2006). Uribelarrea et al. (2009) suggested that the effect of $\mathrm{N}$ stress on stem elongation on grain number occurs indirectly through its effect on photosynthesis and also on phenology stages. Seyed Sharifi (2011) suggested that increasing the number of grains may be due to the delay of the duration of the vegetative and reproductive period and lengthening of grain filling duration.

Table 6. Comparison of means for the experimental factors including genotypes and nitrogen application on number of grains per ear of wheat in two years, 2014-2015

\begin{tabular}{c|c|c|c|c|c}
\hline \multicolumn{2}{|c|}{ Treatment } & \multicolumn{4}{c}{ Number of grains per ear } \\
\hline Year & $\begin{array}{c}\text { Nitrogen } \\
\text { application }\end{array}$ & $\mathbf{G}_{\mathbf{1}}$ & $\mathbf{G}_{\mathbf{2}}$ & $\mathbf{G}_{\mathbf{3}}$ & $\mathbf{G}_{\mathbf{4}}$ \\
\hline \multirow{3}{*}{$\mathrm{Y}_{1}=2014$} & $\mathrm{~N}_{1}$ & $51.67 \mathrm{efg}$ & $55.00 \mathrm{c}-\mathrm{g}$ & $51.50 \mathrm{fg}$ & $53.50 \mathrm{~d}-\mathrm{g}$ \\
& $\mathrm{N}_{2}$ & $66.17 \mathrm{abc}$ & $62.83 \mathrm{a}-\mathrm{e}$ & $55.00 \mathrm{c}-\mathrm{g}$ & $58.17 \mathrm{c}-\mathrm{f}$ \\
& $\mathrm{N}_{3}$ & $54.00 \mathrm{~d}-\mathrm{g}$ & $55.00 \mathrm{c}-\mathrm{g}$ & $45.50 \mathrm{~g}$ & $61.00 \mathrm{~b}-\mathrm{f}$ \\
\hline \multirow{3}{*}{$\mathrm{Y}_{2}=2015$} & $\mathrm{~N}_{1}$ & $58.67 \mathrm{c}-\mathrm{f}$ & $60.83 \mathrm{~b}-\mathrm{f}$ & $64.17 \mathrm{a}-\mathrm{d}$ & $64.33 \mathrm{a}-\mathrm{d}$ \\
& $\mathrm{N}_{2}$ & $55.50 \mathrm{c}-\mathrm{g}$ & $63.00 \mathrm{bcd}$ & $71.67 \mathrm{ab}$ & $73.67 \mathrm{a}$ \\
& $\mathrm{N}_{3}$ & $58.67 \mathrm{c}-\mathrm{f}$ & $59.33 \mathrm{c}-\mathrm{f}$ & $64.50 \mathrm{a}-\mathrm{d}$ & $63.00 \mathrm{a}-\mathrm{d}$ \\
\hline
\end{tabular}

Means in each column followed by similar letter(s) are not significantly different at $5 \%$ probability level, using Duncan's Multiple Range Test

$\mathrm{N} 1, \mathrm{~N} 2$ and N3 indicate (20 kg.ha ${ }^{-1}$ nitrogen fertilizer in sowing and $100 \mathrm{~kg}^{-h^{-1}}$ at mid tillering stage), (20 kg.ha ${ }^{-1}$ nitrogen fertilizer in sowing, $50 \mathrm{~kg} \cdot \mathrm{ha}^{-1}$ at mid tillering and $50 \mathrm{~kg} \cdot \mathrm{ha}^{-1}$ at stem elongation stage) and (20 kg.ha ${ }^{-1}$ nitrogen fertilizer in sowing, $50 \mathrm{~kg} \cdot \mathrm{ha}^{-1}$ at mid tillering and $50 \mathrm{~kg} \cdot \mathrm{ha}^{-1}$ at $50 \%$ of heading stage) respectively

G1, G2, G3 and G4 indicate Zarrin, Peshgam, Orum and Mihan genotypes respectively

\section{Grain yield}

Grain yield is a function of interaction amongst various yield components affected differently by the growing conditions and crop management practices (Cheema et al., 2010). The data presented in Table 8 shows that the interactions of the studied experimental factors (year, irrigation, and genotype) had significant effects on grain yield of wheat. The highest figure for grain yield $(9020 \mathrm{~kg} / \mathrm{ha})$ was observed in 2014 , normal irrigation (I1) and Mihan genotype (G4) (Table 8). Whereas the lowest figure regarding of the abovementioned trait $\left(3277 \mathrm{~kg} \cdot \mathrm{ha}^{-1}\right)$ was obtained in Y2I2G3 (Table 8). The seed yield decreased in water deficit condition except for the Y1I2G3 treatment (Table 8). It is assumed that the obtained reasons are as the result of lower current photosynthesis, stomata conduction, and assimilation in water deficit condition. 
Table 7. Comparison of means for the experimental factors including genotypes and nitrogen application on number of grains per ear of wheat under water limitation

\begin{tabular}{c|c|c|c|c|c}
\hline \multicolumn{2}{c|}{ Treatment } & \multicolumn{4}{c}{ Number of grains per ear } \\
\hline Water limitation & $\begin{array}{c}\text { Nitrogen } \\
\text { application }\end{array}$ & $\mathbf{G}_{\mathbf{1}}$ & $\mathbf{G}_{\mathbf{2}}$ & $\mathbf{G}_{\mathbf{3}}$ & $\mathbf{G}_{\mathbf{4}}$ \\
\hline \multirow{3}{*}{$\mathrm{I}_{1}$} & $\mathrm{~N}_{1}$ & $51.50 \mathrm{c}$ & $58.17 \mathrm{abc}$ & $59.67 \mathrm{abc}$ & $57.50 \mathrm{abc}$ \\
& $\mathrm{N}_{2}$ & $64.33 \mathrm{ab}$ & $65.00 \mathrm{ab}$ & $59.83 \mathrm{abc}$ & $66.33 \mathrm{a}$ \\
& $\mathrm{N}_{3}$ & $61.83 \mathrm{abc}$ & $52.33 \mathrm{c}$ & $55.83 \mathrm{abc}$ & $66.17 \mathrm{a}$ \\
\hline \multirow{3}{*}{$\mathrm{I}_{2}$} & $\mathrm{~N}_{1}$ & $58.83 \mathrm{abc}$ & $57.67 \mathrm{abc}$ & $56.00 \mathrm{abc}$ & $60.33 \mathrm{abc}$ \\
& $\mathrm{N}_{2}$ & $57.33 \mathrm{abc}$ & $60.83 \mathrm{abc}$ & $66.83 \mathrm{a}$ & $65.50 \mathrm{ab}$ \\
& $\mathrm{N}_{3}$ & $50.83 \mathrm{c}$ & $62.00 \mathrm{abc}$ & $54.17 \mathrm{bc}$ & $57.83 \mathrm{abc}$ \\
\hline
\end{tabular}

$I_{1}$ and $I_{2}$ indicate normal irrigation and irrigation withholding in heading stages

Means in each column followed by similar letter(s) are not significantly different at 5\% probability level, using Duncan's Multiple Range Test

$\mathrm{N}_{1}, \mathrm{~N}_{2}$ and $\mathrm{N}_{3}$ indicate (20 kg.ha ${ }^{-1}$ nitrogen fertilizer in sowing and $100 \mathrm{~kg} \cdot \mathrm{ha}^{-1}$ at mid tillering stage), $\left(20 \mathrm{~kg} \cdot \mathrm{ha}^{-1}\right.$ nitrogen fertilizer in sowing, $50 \mathrm{~kg} \cdot \mathrm{ha}^{-1}$ at mid tillering and $50 \mathrm{~kg} \cdot \mathrm{ha}^{-1}$ at stem elongation stage) and (20 kg.ha ${ }^{-1}$ nitrogen fertilizer in sowing, $50 \mathrm{~kg} \cdot \mathrm{ha}^{-1}$ at mid tillering and $50 \mathrm{~kg} \cdot \mathrm{ha}^{-1}$ at $50 \%$ of heading stage) respectively

$\mathrm{G}_{1}, \mathrm{G}_{2}, \mathrm{G}_{3}$ and $\mathrm{G}_{4}$ indicate Zarrin, Peshgam, Orum and Mihan genotypes respectively

Table 8. Comparison of means for the interaction of factors including genotype, water limitation and year on number of grains per ear and grain yield of wheat

\begin{tabular}{c|c|c|c|c|c|c|c|c|c}
\hline \multicolumn{2}{c|}{ Treatment } & \multicolumn{4}{c|}{ Number of grains per ear } & \multicolumn{4}{c}{ Grain yield (kg/ha) } \\
\hline Year & $\begin{array}{c}\text { Water } \\
\text { limitation }\end{array}$ & $\mathbf{G}_{\mathbf{1}}$ & $\mathbf{G}_{\mathbf{2}}$ & $\mathbf{G}_{\mathbf{3}}$ & $\mathbf{G}_{\mathbf{4}}$ & $\mathbf{G}_{\mathbf{1}}$ & $\mathbf{G}_{\mathbf{2}}$ & $\mathbf{G}_{\mathbf{3}}$ & $\mathbf{G}_{\mathbf{4}}$ \\
\hline \multirow{2}{*}{$\mathrm{Y}_{1}=2014$} & $\mathrm{I}_{1}$ & $57.56 \mathrm{cdf}$ & $58.78 \mathrm{~b}-\mathrm{e}$ & $54.56 \mathrm{def}$ & $59.67 \mathrm{~b}-\mathrm{e}$ & $6143 \mathrm{fg}$ & $8537 \mathrm{ab}$ & $5969 \mathrm{~g}$ & $9020 \mathrm{a}$ \\
& $\mathrm{I}_{2}$ & $57.00 \mathrm{c}-\mathrm{e}$ & $56.44 \mathrm{cde}$ & $46.78 \mathrm{f}$ & $55.44 \mathrm{cde}$ & $5180 \mathrm{~h}$ & $7471 \mathrm{e}$ & $6634 \mathrm{f}$ & $7828 \mathrm{cde}$ \\
\hline \multirow{2}{*}{$\mathrm{Y}_{2}=2015$} & $\mathrm{I}_{1}$ & $60.89 \mathrm{~b}-\mathrm{e}$ & $58.22 \mathrm{cde}$ & $70.11 \mathrm{a}$ & $67.00 \mathrm{ab}$ & $7680 \mathrm{de}$ & $8294 \mathrm{bcd}$ & $7775 \mathrm{de}$ & $8464 \mathrm{abc}$ \\
& $\mathrm{I}_{2}$ & $54.33 \mathrm{ef}$ & $63.89 \mathrm{abc}$ & $63.44 \mathrm{a}-\mathrm{d}$ & $67.00 \mathrm{ab}$ & $3409 \mathrm{i}$ & $5794 \mathrm{~g}$ & $3277 \mathrm{i}$ & $5857 \mathrm{~g}$ \\
\hline
\end{tabular}

Means in each column followed by similar letter(s) are not significantly different at $5 \%$ probability level, using Duncan's Multiple Range Test

$I_{1}$ and $I_{2}$ indicate normal irrigation and irrigation withholding at heading stages. $G_{1}, G_{2}, G_{3}$ and $G_{4}$ indicate refer to Zarrin, Pishgam, Orum and Mihan genotypes, respectively

Mihan and Pishgam genotypes had the highest seed yield in contrast to Zarrin genotype showing the lowest seed yield. The high seed yield can be associated with grains per ear, 1000-grain weight, and high photosynthetic contribution of flag leaf and ear to grain filling. These factors indicate that these genotypes are more tolerant of drought stress than the others. Yield reduction was significant in 2015 under water deficit condition resulting in a decrease of 57\% in seed yield in Y2I1G3 compared to Y2I2G3 (Table 8). Results also showed that in normal irrigation (I1), wheat genotypes as $\mathrm{Y} 1 \mathrm{G} 4$ had $7 \%$ more grain yield than Y2G4 (Table 8). However, the available literature has classically considered the flag leaf, leaf below the flag leaf and the ear 
(Tambussi et al., 2007) as the main photosynthetic contributors during grain filling. Water deficit stress affects plant metabolism leading to a decrease in plant growth and grain yield. In the grains of the crops, both current assimilations were transferred directly to grains and remobilization of assimilates were stored in vegetative plant parts contributing to grain yield (Arduini et al., 2006).

\section{Conclusion}

In this research, Mihan and Pyshgam cultivars with the highest seed weight and the transfer of more photosynthetic materials from flag leaf and spike had the highest seed yield in in water deficit conditions. According to the results, the application of $\mathrm{N}$ fertilizer in different doses and times, on different genotypes can be a proper tool for increasing wheat yield under water deficit condition.

\section{REFERENCES}

[1] Abebe, T., Guenzi, A. C., Martin, B., Cushman, J. C. (2003): Tolerance of mannitolaccumulating transgenic wheat to water stress and salinity. - Plant Physiology 131: 17481755.

[2] Ahmad, N., Basra, S., Qureshi, R., Ahmad, S. (1988): Grain development in wheat as affected by different nitrogen levels under warm dry conditions. - Pakistan Journal of Agricultural Science 25: 225-231.

[3] Ahmadi, A., Isvand, H., Postini, K. (2006): Intraction of drought stress and nitrogen application timing on yield and physiological traits in winter wheat. - Iranian Journal of Field Crop Science 37: 113-123.

[4] Akinrinde, E. A. (2006): Growth regulator and nitrogen fertilization effects on performance and nitrogen-use efficiency of tall and dwarf varieties of rice (Oryza sativa L.). - Biotechnology 5: 268-276.

[5] Alam, M., Haider, S. (2006): Growth attributes of barley (Hordeum vulgare L.) cultivars in relation to different doses of nitrogen fertilizer. - Journal of Life and Earth Science 1: 77-82.

[6] Alam, M., Jahan, M., Ali, M., Ashraf, M., Islam, M. (2007): Effect of vermicompost and chemical fertilizers on growth, yield and yield components of potato in barind soils of Bangladesh. - Journal of Applied Sciences Research 3: 1879-1888.

[7] Amiri, R., Bahraminejad, S., Jalali-Honarmand, S. (2013): Effect of terminal drought stress on grain yield and some morphological traits in 80 bread wheat genotypes. International Journal of Agriculture and Crop Sciences 5: 1145.

[8] Arduini, I., Masoni, A., Ercoli, L., Mariotti, M. (2006): Grain yield, and dry matter and nitrogen accumulation and remobilization in durum wheat as affected by variety and seeding rate. - European Journal of Agronomy 25: 309-318.

[9] Azarpanah, A., Alizadeh, O., Dehghanzadeh, H., Zare, M. (2013): The effect of irrigation levels in various growth stages on morphological characteristics and yield components of Zea mays L. - Technical Journal of Engineering and Applied Scinces 3: 1447-1459.

[10] Cheema, M., Farhad, W., Saleem, M., Khan, H., Munir, A., Wahid, M., Rasul, F., Hammad, H., Cheema, M., Farhad, W. (2010): Nitrogen management strategies for sustainable maize production. - Crop Environment 1: 49-52.

[11] Dawadi, D., Sah, S. (2012): Growth and yield of hybrid maize (Zea mays L.) in relation to planting density and nitrogen levels during winter season in Nepal. - Tropical Agricultural Research 23(3): 218-227.

[12] Diacono, M., Rubino, P., Montemurro, F. (2013): Precision nitrogen management of wheat. A review. - Agronomy for Sustainable Development 33: 219-241. 
[13] Dordas, C. A., Sioulas, C. (2008): Safflower yield, chlorophyll content, photosynthesis, and water use efficiency response to nitrogen fertilization under rainfed conditions. Industrial Crops and Products 27: 75-85.

[14] Ehdaie, B., Alloush, G., Waines, J. (2008): Genotypic variation in linear rate of grain growth and contribution of stem reserves to grain yield in wheat. - Field Crops Research 106: 34-43.

[15] Lawrence, J. R., Ketterings, Q., Cherney, J. (2008): Effect of nitrogen application on yield and quality of silage corn after forage legume-grass. - Agronomy journal 100: 7379.

[16] Maccaferri, M., Sanguineti, M. C., Demontis, A., El-Ahmed, A., Garcia Del Moral, L., Maalouf, F., Nachit, M., Nserallah, N., Ouabbou, H., Rhouma, S. (2011): Association mapping in durum wheat grown across a broad range of water regimes. - Journal of Experimental Botany 62: 409-438.

[17] Maydup, M. L., Antonietta, M., Guiamet, J., Graciano, C., López, J. R., Tambussi, E. A. (2010): The contribution of ear photosynthesis to grain filling in bread wheat (Triticum aestivum L.). - Field Crops Research 119: 48-58.

[18] Olszewski, J., Pszczółkowska, A., Kulik, T., Fordoński, G., Płodzień, K., Okorski, A., Wasielewska, J. (2008): Rate of photosynthesis and transpiration of winter wheat leaves and ears under water deficit conditions. - Polish Journal of Natural Sciences 23: 326-335.

[19] Osman, A. R. (2014): Improving some quantitative and qualitative characteristics of Solidago canadensis 'Tara' using cycocel and planting density under drip irrigation and lighting systems. - Life Science Journal 11: 110-118.

[20] Sadras, V. O., Egli, D. (2008): Seed size variation in grain crops: allometric relationships between rate and duration of seed growth. - Crop Science 48: 408-416.

[21] Sanjari, A., Yazdan Sepas, A. (2008): Stem reservation genetic variation of bread wheat genotypes under drought stress condition after anthesis stage. - Iranian Journal of Crop Sciences 29: 181-191.

[22] Seyed Sharifi, R., Khavazi, K. (2011): Effects of seed priming with Plant Growth Promoting Rhizobacteria (PGPR) on yield and yield attribute of maize (Zea mays L.) hybrids. - Journal of Food, Agriculture and Environment 9: 496-500.

[23] Soleymanifard, A., Sidat, S. (2011): Effect of inoculation with biofertilizer in different nitrogen levels on yield and yields components of safflower under dry land conditions. American-Eurasian Journal Agriculture and Environment Science 11: 473-477.

[24] Tambussi, E. A., Bort, J., Guiamet, J. J., Nogués, S., Araus, J. L. (2007): The photosynthetic role of ears in C3 cereals: metabolism, water use efficiency and contribution to grain yield. - Critical Reviews in Plant Sciences 26: 1-16.

[25] Uribelarrea, M., Crafts-Brandner, S. J., Below, F. E. (2009): Physiological N response of field-grown maize hybrids (Zea mays L.) with divergent yield potential and grain protein concentration. - Plant and soil 316: 151.

[26] Wang, H., Xiao, L. (2009): Effects of chlorocholine chloride on phytohormones and photosynthetic characteristics in potato (Solanum tuberosum L.). - Journal of Plant Growth Regulation 28: 21.

[27] Wei-Wei, M., Dong, W., Zhen-Wen, Y. (2012): Effects of nitrogen fertilizer on activities of nitrogen metabolism related enzymes and grain Protein quality of wheat. - Plant Nutr. Fert. Sci. 18(1): 10-17.

[28] Zeidan, M., Amany, A., El-Kramany, M. (2006): Effect of N-fertilizer and plant density on yield and quality of maize in sandy soil. - Research Journal of Agriculture and Biology Science 2: 156-161. 


\section{APPENDIX}

Appendix 1. Study site. The pollination stage in wheats are shown. In this stage samples were treated for determining the phenotypic manipulations components, e.g. all the leaves below the flag leaf, flag leaf and half of the spike were removed in samples

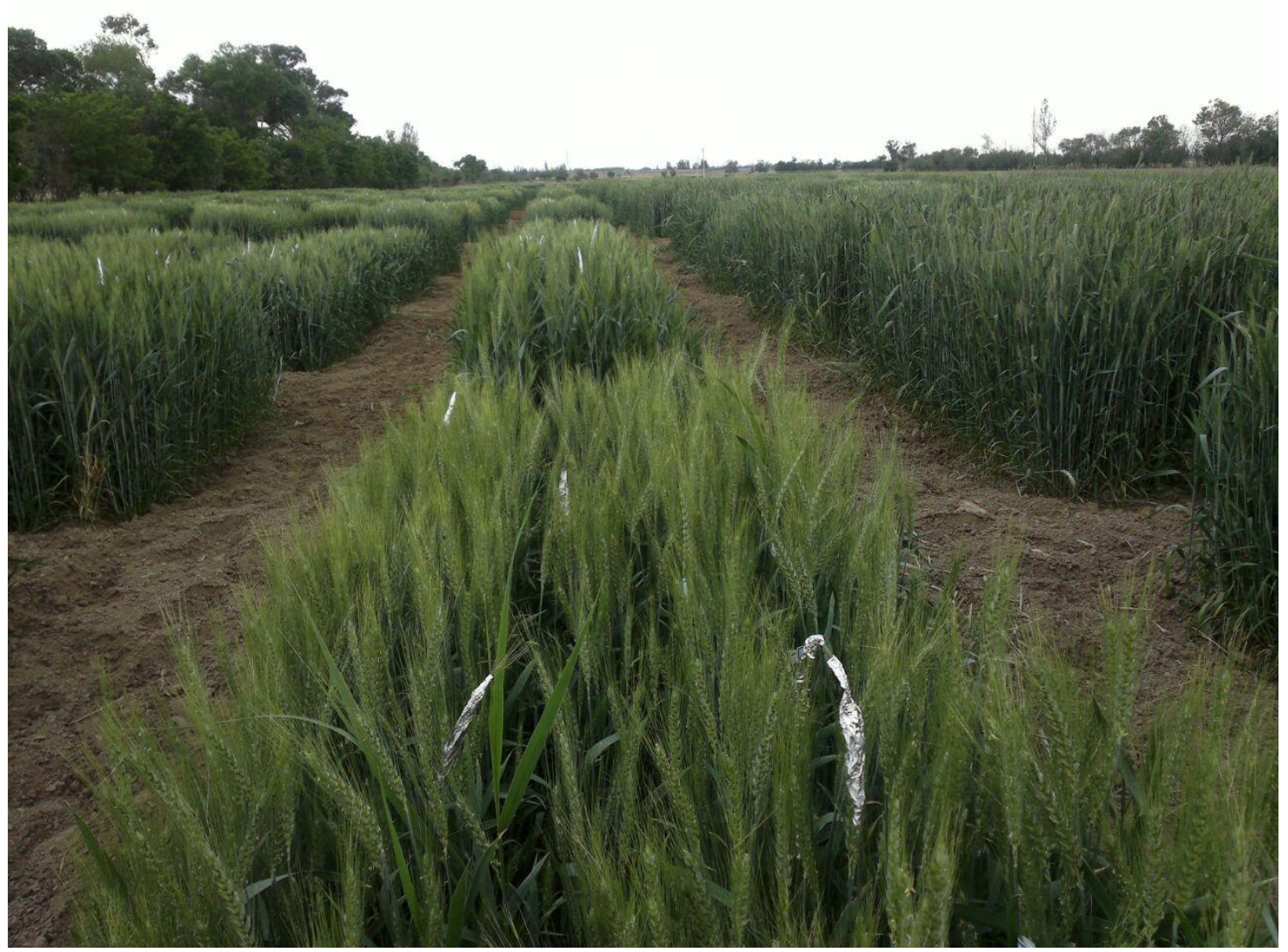


Appendix 2. Experimental design: a split plot based randomized complete block design with three replications

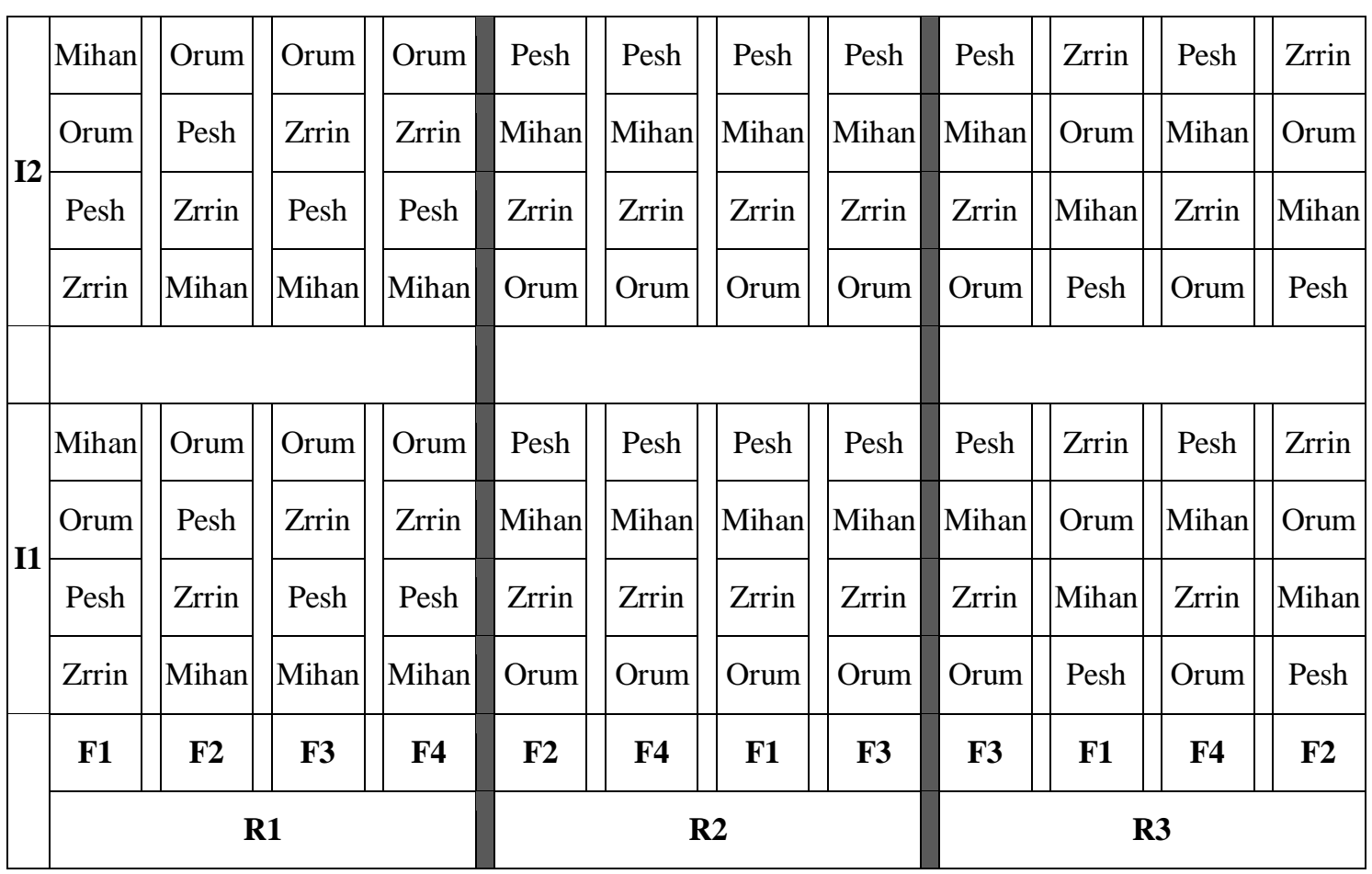

I1 and I2 indicate normal irrigation and irrigation withholding in heading stages. N1, N2 and N3 indicate $\left(20 \mathrm{~kg} \cdot \mathrm{ha}^{-1}\right.$ nitrogen fertilizer in sowing and $100 \mathrm{~kg} \cdot \mathrm{ha}^{-1}$ at mid tillering stage), $\left(20 \mathrm{~kg} \cdot \mathrm{ha}^{-1}\right.$ nitrogen fertilizer in sowing, $50 \mathrm{~kg} \cdot \mathrm{ha}^{-1}$ at mid tillering and $50 \mathrm{~kg} \cdot \mathrm{ha}^{-1}$ at stem elongation stage) and $\left(20 \mathrm{~kg} \cdot \mathrm{ha}^{-1}\right.$ nitrogen fertilizer in sowing, $50 \mathrm{~kg} \cdot \mathrm{ha}^{-1}$ at mid tillering and $50 \mathrm{~kg} \cdot \mathrm{ha}^{-1}$ at $50 \%$ of heading stage) respectively

Zarrin, Peshgam, Orum and Mihan genotypes respectively 